\title{
Effect of Dietary Crude Protein Concentration on Milk Production and Nitrogen Utilization in Lactating Dairy Cows ${ }^{1}$
}

\author{
J. J. Olmos Colmenero*2 and G. A. Broderick ${ }^{3}$ \\ *Department of Dairy Science, University of Wisconsin, Madison 53706 \\ †Agricultural Research Service, USDA US Dairy Forage Research Center, 1925 Linden Drive West, Madison, WI 53706
}

\begin{abstract}
Forty lactating Holstein cows, including 10 with ruminal cannulas, were blocked by days in milk into 8 groups and then randomly assigned to 1 of 8 incomplete $5 \times 5$ Latin squares to assess the effects of 5 levels of dietary crude protein $(\mathrm{CP})$ on milk production and $\mathrm{N}$ use. Diets contained $25 \%$ alfalfa silage, $25 \%$ corn silage, and $50 \%$ concentrate, on a dry matter (DM) basis. Rolled highmoisture shelled corn was replaced with solvent-extracted soybean meal to increase CP from 13.5 to 15.0, $16.5,17.9$, and $19.4 \%$ of DM. Each of the 4 experimental periods lasted $28 \mathrm{~d}$, with $14 \mathrm{~d}$ for adaptation and $14 \mathrm{~d}$ for data collection. Spot sampling of ruminal digesta, blood, urine, and feces was conducted on d 21 of each period. Intake of DM was not affected by diet but milk fat content as well as ruminal acetate, $\mathrm{NH}_{3}$, and branchedchain volatile fatty acids, urinary allantoin, and blood and milk urea all increased linearly with increasing CP. Milk and protein yield showed trends for quadratic responses to dietary CP and were, respectively, 38.3 and $1.18 \mathrm{~kg} / \mathrm{d}$ at $16.5 \% \mathrm{CP}$. As a proportion of $\mathrm{N}$ intake, urinary $\mathrm{N}$ excretion increased from 23.8 to $36.2 \%$, whereas $\mathrm{N}$ secreted in milk decreased from 36.5 to $25.4 \%$, as dietary protein increased from 13.5 to $19.4 \%$. Under the conditions of this study, yield of milk and protein were not increased by feeding more than $16.5 \% \mathrm{CP}$. The linear increase in urinary $\mathrm{N}$ excretion resulted from a sharp decline in $\mathrm{N}$ efficiency as dietary $\mathrm{CP}$ content increased.
\end{abstract}

Key words: dietary crude protein, milk production, nitrogen utilization

\footnotetext{
Received June 6, 2005.

Accepted January 4, 2006.

${ }^{1}$ Mention of any trademark or proprietary product in this paper does not constitute a guarantee or warranty of the product by the USDA or the Agricultural Research Service and does not imply its approval to the exclusion of other products that also may be suitable.

${ }^{2}$ Present address: Centro Universitario de los Altos, Universidad de Guadalajara, Carretera a Yahualica Km. 7.5, Tepatitlan de Morelos, Jalisco, Mexico CP 47600.

${ }^{3}$ Corresponding author: gbroderi@wisc.edu
}

\section{INTRODUCTION}

Producers often feed high CP diets to ensure a sufficient supply of the MP required for maximal milk and protein production of dairy cows. A survey of 6 Wisconsin dairy farms with mean rolling herd averages of 14,140 $\mathrm{kg}$ indicated lactating cows were fed diets averaging $19.1 \% \mathrm{CP}$ of DM, with a range from 18.0 to $21.5 \%$ (Gunderson et al., 1998). However, several studies have reported no improvement in milk and protein production when dietary $\mathrm{CP}$ was increased from 16.1-16.7\% to 18.418.9\% (Cunningham et al., 1996; Broderick, 2003; Leonardi et al., 2003).

It is well established that, as the $\mathrm{CP}$ content of the diet increases, the amount of protein degraded in the rumen also increases. If RDP exceeds microbial needs, then large amounts of $\mathrm{NH}_{3}$ are produced, absorbed into the blood, converted to urea in the liver, and excreted in the urine. In the manure, urinary urea can be rapidly hydrolyzed to $\mathrm{NH}_{3}$ and lost by volatilization to the environment (Muck, 1982). Overfeeding CP also reduces profit margins because of the relatively high cost of protein supplements and the poor efficiency of $\mathrm{N}$ use by dairy cows fed high protein diets (Broderick, 2003).

Although a wide range of RDP values have been reported for solvent-extracted soybean meal (SSBM), the most common protein source fed to dairy cows in the United States, an overall mean of about $65 \%$ is given by NRC (2001). Substitution of high RUP sources in dairy diets often has been used to increase MP flow to the small intestine. However, reviews by Santos et al. (1998) and Ipharraguerre and Clark (2005) summarized data showing that adding RUP to the diet, at the expense of SSBM, often had little effect on MP supply because of depressed ruminal formation of microbial NAN. A recent trial indicated that omasal flow of bacterial and total NAN decreased linearly, despite increased flow of nonmicrobial NAN, when lignosulfonate-treated soybean meal replaced SSBM in the diet (Reynal and Broderick, 2005).

Therefore, the objective of this study was to determine the optimum $\mathrm{CP}$ content of the diet required to maximize production of milk and protein at minimal $\mathrm{N}$ excretion by cows fed diets formulated from typical US ingredients. 
Table 1. Composition of feeds ${ }^{1}$

\begin{tabular}{|c|c|c|c|c|c|c|c|c|c|c|}
\hline Item & \multicolumn{2}{|c|}{ Alfalfa silage } & \multicolumn{2}{|c|}{ Corn silage } & \multicolumn{2}{|c|}{ RHMSC } & \multicolumn{2}{|c|}{ SSBM } & \multicolumn{2}{|c|}{ RSB } \\
\hline $\mathrm{DM}, \%$ & 44.2 & 5.8 & 41.2 & 2.7 & 72.4 & 1.6 & 91.1 & 0.9 & 97.7 & 0.5 \\
\hline Ash, \% of DM & 10.7 & 0.8 & 4.13 & 0.36 & 1.95 & 0.28 & 7.52 & 0.19 & 5.40 & 0.58 \\
\hline $\mathrm{NDF}, \%$ of $\mathrm{DM}$ & 35.8 & 4.4 & 36.1 & 2.1 & 8.32 & 0.75 & 8.06 & 0.46 & 23.9 & 0.9 \\
\hline $\mathrm{ADF}, \%$ of $\mathrm{DM}$ & 27.0 & 3.8 & 18.3 & 0.8 & 1.97 & 0.18 & 4.57 & 0.41 & 4.04 & 1.40 \\
\hline Neutral detergent insoluble CP, \% of DM & 1.41 & 0.76 & 0.28 & 0.03 & 0.18 & 0.08 & 0.26 & 0.10 & 3.30 & 0.50 \\
\hline $\mathrm{NH}_{3} \mathrm{~N}, \%$ of total $\mathrm{N}$ & 6.48 & 3.55 & 8.69 & 1.76 & 3.64 & 1.27 & - & - & - & - \\
\hline Free AA N, \% of total N & 25.9 & 4.7 & 36.3 & 6.3 & 20.3 & 2.9 & - & - & - & - \\
\hline Unidentified NAN, $\%$ of total NPN & 14.0 & 1.9 & 10.9 & 1.6 & 7.32 & 1.18 & - & - & - & - \\
\hline
\end{tabular}

${ }^{1}$ RHMSC = Rolled high-moisture shelled corn; RSB = roasted soybeans; and SSBM = solvent-extracted soybean meal.

\section{MATERIALS AND METHODS}

\section{Experimental Procedure}

Thirty-eight multiparous and 2 primiparous Holstein cows (8 multiparous and 2 primiparous cows were ruminally cannulated) averaging 120 DIM (SD 76), 2.5 parity (SD 1.1), $589 \mathrm{~kg}$ of BW (SD 58), and $41 \mathrm{~kg}$ of milk/d (SD 6) were blocked by DIM into 8 groups (2 groups of ruminally cannulated animals) then randomly assigned to 1 of 8 diet sequences in an incomplete $5 \times 5$ Latin square ( 5 diets and 4 periods). This design, rather than a complete $5 \times 5$ Latin square, was used because there was insufficient alfalfa and corn silage to complete a fifth period. The duration of each experimental period was $28 \mathrm{~d}$ with $14 \mathrm{~d}$ for diet adaptation and $14 \mathrm{~d}$ for collection of data. Cows were held in tie stalls for the duration of the experiment, had free access to water, and were weighed on 3 consecutive days at the beginning and at the end of each period. All animals were injected with recombinant bST (500 mg of Posilac; Monsanto, St. Louis, MO) every $14 \mathrm{~d}$ starting on the first day of the experiment. Animal care and experimental procedures met the requirements of the Institutional Animal Care and Use Committee of the UW-Madison (Research Animal Resources Center protocol \# A-07-3400-A00286). Two intact cows had sharp drops in milk yield during the last 2 wk of period 1 and were removed from the experiment; one ruminally cannulated cow was removed from the trial after period 3 for health reasons unrelated to the experiment.

The experimental diets were fed as TMR and contained $25 \%$ alfalfa silage, $25 \%$ corn silage, and $50 \%$ of a concentrate (DM basis) formulated principally from rolled high-moisture shelled corn (RHMSC), SSBM, and roasted soybeans. Dietary CP was increased in increments of approximately 1.5 percentage units, from 13.5 to $19.4 \%$, by replacing RHMSC with SSBM. Cows were fed once daily at about $1600 \mathrm{~h}$ and feed offered was adjusted daily to yield 5 to $10 \%$ orts. Samples of individual feeds and orts (about $0.5 \mathrm{~kg}$ ) were taken daily, and stored at $-20^{\circ} \mathrm{C}$. Weekly composite samples from feeds and orts were dried at $60^{\circ} \mathrm{C}$ for $48 \mathrm{~h}$ and the as-fed composition of the diets was adjusted every week. Weekly feed composites were ground through a 1-mm screen (Wiley mill, Arthur H. Thomas, Philadelphia, PA) and analyzed for $\mathrm{DM}$ at $105^{\circ} \mathrm{C}$ (AOAC, 1980) and for total N (Leco 2000; Leco Instruments, Inc., St. Joseph, MI) to adjust diets to the desired $\mathrm{CP}$ content (total $\mathrm{N} \times$ 6.25) every week. Intake of DM was corrected for orts and recorded daily throughout the experiment. Feed samples were analyzed sequentially for NDF and ADF (Van Soest et al., 1991) using heat-stable amylase and sodium sulfite (Hintz et al., 1995) in an Ankom Fiber Analyzer (Ankom Technology Corp., Fairport, NY). The N content of NDF residues was analyzed by combustion assay (Leco Instruments Inc.). Ash and OM contents of feeds were also measured (AOAC, 1980). Weekly samples of alfalfa silage, corn silage, and RHMSC were thawed, water extracts were prepared (Muck, 1987), and $\mathrm{pH}$ was measured. Extracts were then deproteinized and analyzed for NPN as described by Muck (1987), and for $\mathrm{NH}_{3}$ and total free AA by flow-injection analysis as described by Broderick et al. (2004). Chemical composition of the principal dietary ingredients and the composition of the diets, reported in Tables 1 and 2, are averages from wk 3 and wk 4 of all 4 experimental periods.

Cows were milked twice daily and milk weights were recorded at each milking. On d 20 and 27 of each period, a.m. and p.m. milk samples were collected, preserved with 2-bromo-2-nitropropane-1,3-diol, and analyzed for fat, true protein, lactose, SNF, and MUN content by infrared methods (AgSource Laboratory, Verona, WI). On d 22 of each period, samples of rumen fluid were collected from 2 locations in the midventral ruminal sac of cannulated cows starting at 0 (just before feeding), 1 , $2,4,8,12,18$, and $24 \mathrm{~h}$ after feeding. Samples were 
Table 2. Composition of diets

\begin{tabular}{|c|c|c|c|c|c|}
\hline \multirow[b]{2}{*}{ Item $^{1}$} & \multicolumn{5}{|c|}{ Diets } \\
\hline & $\mathrm{A}$ & $\mathrm{B}$ & $\mathrm{C}$ & $\mathrm{D}$ & $\mathrm{E}$ \\
\hline & \multicolumn{5}{|c|}{$\longrightarrow(\%$ of $\mathrm{DM})$} \\
\hline Alfalfa silage & 25.0 & 25.0 & 25.0 & 25.0 & 25.0 \\
\hline Corn silage & 25.0 & 25.0 & 25.0 & 25.0 & 25.0 \\
\hline RHMSC & 44.0 & 40.6 & 37.2 & 33.8 & 30.4 \\
\hline SSBM & 2.4 & 5.8 & 9.2 & 12.6 & 16.0 \\
\hline Roasted soybeans & 2.5 & 2.5 & 2.5 & 2.5 & 2.5 \\
\hline Sodium bicarbonate & 0.6 & 0.6 & 0.6 & 0.6 & 0.6 \\
\hline Salt & 0.2 & 0.2 & 0.2 & 0.2 & 0.2 \\
\hline Dicalcium phosphate & 0.2 & 0.2 & 0.2 & 0.2 & 0.2 \\
\hline Vitamin-mineral premix ${ }^{2}$ & 0.1 & 0.1 & 0.1 & 0.1 & 0.1 \\
\hline \multicolumn{6}{|l|}{ Chemical composition } \\
\hline $\mathrm{DM}, \%$ & 54.1 & 54.3 & 54.6 & 54.9 & 55.2 \\
\hline $\mathrm{CP}$ & 13.5 & 15.0 & 16.5 & 17.9 & 19.4 \\
\hline Ash & 5.97 & 6.16 & 6.35 & 6.54 & 6.73 \\
\hline $\mathrm{NDF}$ & 22.4 & 22.4 & 22.4 & 22.4 & 22.4 \\
\hline $\mathrm{ADF}$ & 12.4 & 12.5 & 12.6 & 12.7 & 12.8 \\
\hline NDICP & 0.50 & 0.55 & 0.59 & 0.63 & 0.68 \\
\hline $\mathrm{RDP}^{3}$ & 9.3 & 10.2 & 11.0 & 11.9 & 12.7 \\
\hline RUP $^{3}$ & 4.2 & 4.8 & 5.5 & 6.0 & 6.7 \\
\hline $\mathrm{NFC}^{3}$ & 55.0 & 53.5 & 51.9 & 50.4 & 48.8 \\
\hline Discounted total digestible nutrients ${ }^{3}$ & 66.2 & 65.9 & 65.5 & 65.8 & 65.4 \\
\hline $\mathrm{NE}_{\mathrm{L}},{ }^{3} \mathrm{Mcal} / \mathrm{kg}$ of DM & 1.59 & 1.59 & 1.60 & 1.62 & 1.62 \\
\hline \multicolumn{6}{|c|}{$\begin{array}{l}{ }^{1} \text { NDICP = Neutral detergent insoluble CP; RHMSC = rolled high-moisture shelled corn; and SSBM = } \\
\text { solvent-extracted soybean meal. }\end{array}$} \\
\hline \multicolumn{6}{|c|}{$\begin{array}{l}{ }^{2} \text { Provided per kilogram of DM: } 56 \mathrm{mg} \text { of } \mathrm{Zn}, 46 \mathrm{mg} \text { of } \mathrm{Mn}, 22 \mathrm{mg} \text { of } \mathrm{Fe}, 12 \mathrm{mg} \text { of Cu, } 0.9 \mathrm{mg} \text { of I, } 0.4 \mathrm{mg} \\
\text { of } \mathrm{Co}, 0.3 \mathrm{mg} \text { of Se, } 6,440 \mathrm{IU} \text { of vitamin A, } 2,000 \mathrm{IU} \text { of vitamin } \mathrm{D} \text {, and } 16 \mathrm{IU} \text { of vitamin } \mathrm{E} .\end{array}$} \\
\hline \multicolumn{6}{|c|}{${ }^{3}$ Computed using NRC (2001) model based on actual composition of feeds, least squares means of actual } \\
\hline
\end{tabular}

withdrawn using a $60-\mathrm{mL}$ plastic syringe with a regular Luer tip using a metal filter probe. The filter of the probe, a cylinder $7.5 \mathrm{~cm}$ long and $1.8 \mathrm{~cm}$ in diameter with $1.0-$ $\mathrm{mm}$ diameter holes, was welded to a $1 \mathrm{~m}$ long metal tube with internal diameter of $0.5 \mathrm{~cm}$. The $\mathrm{pH}$ of the samples was measured immediately, and $20 \mathrm{~mL}$ of rumen fluid was acidified with $0.4 \mathrm{~mL}$ of $50 \%$ ( $\mathrm{vol} / \mathrm{vol}$ ) sulfuric acid and stored at $-20^{\circ} \mathrm{C}$ for later analysis of VFA (Brotz and Schaefer, 1987), total free AA, and $\mathrm{NH}_{3}$ (Broderick et al., 2004). Blood was sampled into heparinized test tubes from the coccygeal artery or vein of each cow at $4 \mathrm{~h}$ after feeding on $\mathrm{d} 21$ of each period; heparinized blood was held on ice until returning to the laboratory. Blood was deproteinized by mixing $1.25 \mathrm{~mL}$ of $25 \%$ (wt/vol) TCA with $5 \mathrm{~mL}$ of whole blood and then centrifuging $\left(15,000 \times g, 4^{\circ} \mathrm{C}, 15 \mathrm{~min}\right)$; supernatants were stored at $-20^{\circ} \mathrm{C}$ until analyzed for urea (Broderick and Clayton, 1997).

Spot urine and fecal samples were collected from every cow on d 21 of each period at about $6 \mathrm{~h}$ before and after feeding. Previously, this spot-sampling scheme yielded estimates of purine derivative excretion that were similar to total urine collection (Valadares et al., 1999). Fecal samples were dried in a forced-draft oven at $60^{\circ} \mathrm{C}$ for 72 $\mathrm{h}$ and ground through a 1-mm screen (Wiley mill). Equal amounts of DM from the a.m. and p.m. samples from each cow were composited to yield 29 to 32 separate samples per diet, and analyzed for $\mathrm{DM}\left(105^{\circ} \mathrm{C}\right)$, ash, $\mathrm{OM}$, $\mathrm{NDF}, \mathrm{ADF}$, and $\mathrm{N}$ as described earlier for feeds. Total tract apparent digestibility of nutrients was estimated using the indigestible $\mathrm{ADF}$ content (ADF remaining after 12-d in situ incubations; Huhtanen et al., 1994) in feces and TMR as an internal marker. Urine samples $(15 \mathrm{~mL})$ were acidified with $60 \mathrm{~mL}$ of $0.072 \mathrm{~N} \mathrm{H}_{2} \mathrm{SO}_{4}$, and immediately stored at $-20^{\circ} \mathrm{C}$. After thawing, urine samples were analyzed for total N (Mitsubishi TN-05 Nitrogen Analyzer; Mitsubishi Chemical Corp., Tokyo, Japan), and for urea (Broderick and Clayton, 1997) and creatinine (Oser, 1965) by flow injection (Lachat QuickChem 8000 FIA; Zellweger Analytical, Milwaukee, WI). Urine volume was computed using creatinine as a marker assuming a creatinine excretion of $29 \mathrm{mg} / \mathrm{kg}$ of BW per day (Valadares et al., 1999). Allantoin (Vogels and van der Drift, 1970) and uric acid (kit no. 1830, Thermo DMA, Waltham, MA) were also determined in urine using assays adapted to a 96 -well plate reader.

\section{Statistical Analyses}

Average intake and milk production data from each cow over the last $14 \mathrm{~d}$ of each period were analyzed as a Latin square design using the mixed procedures of 
SAS (SAS Institute, 1999). Because of missing data, there were 31 observations each for diets B and E, 30 observations for diets $\mathrm{A}$ and $\mathrm{D}$, and 29 observations for diet C. Model sums of squares were separated into overall mean, cow (within square), square, period, diet (treatment effect), and square $\times$ treatment interaction. All variables were considered fixed, except cow (within square) and overall error, which were considered random. The interaction term square $\times$ treatment was removed from the model when $P \geq 0.25$. Linear and quadratic effects of treatments were also estimated. Eight complete sets of ruminal samples were obtained on diets $\mathrm{A}, \mathrm{B}, \mathrm{D}$, and $\mathrm{E}$, but only 7 sets for diet $\mathrm{C}$ because one ruminally cannulated cow did not complete period 4 . Model sums of squares for data collected at different times after feeding (ruminal $\mathrm{pH}$ and concentrations of VFA, $\mathrm{NH}_{3}$, and total free $\mathrm{AA}$ ) were separated into overall mean, cow (within square), square, period, diet (treatment effect), square $\times$ treatment interaction, whole-plot error, hours postfeeding (repeated measures), hours postfeeding $\times$ treatment interaction, and subplot error. Repeated measures analyses were performed using the $\mathrm{SP}(\mathrm{POW})$ structure of SAS. All variables were considered fixed, except cow (within square), whole-plot error, and subplot error, which were considered random. The interaction term square $\times$ treatment was removed from the model when $P \geq 0.25$. Linear and quadratic effects of treatments were also estimated. Significance was declared at $P \leq 0.05$ and trends at $P \leq 0.10$. Variables showing quadratic effects that were significant at $P \leq$ 0.10 were regressed on dietary $\mathrm{CP}$ concentration using the mixed procedures of SAS (SAS Institute, 1999) to obtain intercept and linear and quadratic coefficients of the regression model. These equations were solved for dietary $\mathrm{CP}$ concentrations at which these variables were maximal or minimal.

\section{RESULTS AND DISCUSSION}

\section{Composition of Diets}

The composition of dietary ingredients is presented in Table 1. Low NDF and ADF contents of the alfalfa silage and corn silage (Table 1) indicated that both forages were of very high quality. Mean NPN content of alfalfa silage was $46.3 \%$ of total $\mathrm{N}$, which was lower than the average of 54\% from 19 experiments reported by Broderick (1995). The lower NPN content may have improved CP use in the current trial (Nagel and Broderick, 1992). The RHMSC, roasted soybeans, and SSBM contained 8.4, 40.0, and 52.0\% CP (DM basis), respectively. Low variation in $\mathrm{CP}$ content of all dietary ingredients (Table 1) made it possible to maintain the 5 experimental diets close to target $\mathrm{CP}$ concentrations throughout the $16 \mathrm{wk}$ of the trial (Table 2). The NDF and ADF contents of the diets were similar among treatments but probably did not meet the requirements of these cows because the fiber levels in both the alfalfa and corn silages were about 10 percentage units below the averages reported in NRC (2001). Conversely, the estimated NFC contents (NRC, 2001) of all diets were quite high (49 to 55\% of DM) compared with NRC (2001) recommendations (42\% DM). However, no apparent detrimental effects of diets were observed either on ruminal $\mathrm{pH}$ or on cow health.

\section{Milk Yield and Composition}

Although CP content of diets fed in this trial covered a wide range ( 13.5 to $19.4 \%$ of DM), only a few production traits were affected (Table 3). Intake of DM, yield of milk, and FCM were not significantly affected. However, milk and FCM yields showed trends for quadratic $(P=$ $0.10)$ and linear $(P=0.10)$ responses to dietary $\mathrm{CP}$, respectively. Milk yield increased from $36.3 \mathrm{~kg} / \mathrm{d}$ at $13.5 \%$ CP to $38.3 \mathrm{~kg} / \mathrm{d}$ at $16.5 \% \mathrm{CP}$, then declined to 36.6 and $37.0 \mathrm{~kg} / \mathrm{d}$ at 17.9 and $19.4 \% \mathrm{CP}$, respectively. Protein and fat yields also showed quadratic $(P=0.09)$ and linear $(P=0.06)$ trends; both traits reached maxima (1.18 and $1.24 \mathrm{~kg} / \mathrm{d}$ ) at $16.5 \% \mathrm{CP}$, with no further improvement at higher dietary CP. Fat content of milk increased linearly $(P<0.01)$, and SNF showed a linear trend $(P=0.08)$, with increasing $\mathrm{CP}$ content of the diet but there was no effect of dietary $\mathrm{CP}$ on milk protein content, lactose content and yield, SNF yield, BW change, or feed efficiency (milk/DMI).

In agreement with our findings, Cunningham et al. (1996) and Leonardi et al. (2003) observed no effect of dietary CP content on DMI and milk yield of dairy cows when dietary CP was increased from 16.5 to $18.5 \%$ and from 16.1 to $18.9 \%$, respectively. On the other hand, Broderick (2003) reported a linear increase in DMI when dietary CP was increased from 15.1 to 16.7 and 18.3\%; however, milk yield increased from 33.0 to $34.1 \mathrm{~kg} / \mathrm{d}$ only with the first $\mathrm{CP}$ increment, with no further change at $18.3 \% \mathrm{CP}$, resulting in lower feed efficiency (milk/DMI) at the highest CP. Broderick (2003) also reported that yields of fat and protein improved when the dietary $\mathrm{CP}$ increased from 15.1 to 16.7 but with no further increase at $18.4 \%$ CP. Leonardi et al. (2003) found that protein yield was unaffected (1.35 and $1.34 \mathrm{~kg} / \mathrm{d})$ and milk protein content actually decreased (3.25 and $3.18 \%)$ when dietary CP was increased from 16.1 to $18.9 \%$; however, fat content and yield increased significantly in response to dietary CP. These reports and the current trial are consistent with the pattern shown in the much larger databases of NRC (2001) and the reviews of Huhtanen and Shingfield (2005) and Ipharraguerre and Clark (2005), indicating that milk yield increased at a substantially lower rate at higher dietary $\mathrm{CP}$ than at lower 
Table 3. Effect of dietary CP content on milk production and composition

\begin{tabular}{|c|c|c|c|c|c|c|c|c|c|}
\hline \multirow[b]{2}{*}{ Item } & \multicolumn{5}{|c|}{ Dietary CP, \% of DM } & \multirow[b]{2}{*}{$\mathrm{SE}^{2}$} & \multicolumn{3}{|c|}{$P>\mathrm{F}^{1}$} \\
\hline & 13.5 & 15.0 & 16.5 & 17.9 & 19.4 & & Diet & $\mathrm{L}$ & $\mathrm{Q}$ \\
\hline DM intake, kg/d & 22.3 & 22.2 & 23.0 & 22.3 & 22.9 & 0.5 & 0.25 & 0.22 & 0.93 \\
\hline Milk yield, kg/d & 36.3 & 37.2 & 38.3 & 36.6 & 37.0 & 1.01 & 0.17 & 0.65 & 0.10 \\
\hline $3.5 \% \mathrm{FCM}, \mathrm{kg} / \mathrm{d}$ & 34.2 & 35.6 & 36.7 & 35.7 & 36.1 & 1.09 & 0.22 & 0.10 & 0.16 \\
\hline BW change, $\mathrm{kg} / \mathrm{d}$ & 0.49 & 0.46 & 0.70 & 0.55 & 0.64 & 0.11 & 0.49 & 0.24 & 0.74 \\
\hline Milk/DMI & 1.71 & 1.71 & 1.71 & 1.71 & 1.72 & 0.04 & 1.00 & 0.89 & 0.96 \\
\hline \multicolumn{10}{|l|}{ Milk composition and yield } \\
\hline Fat, $\%$ & $3.14^{\mathrm{b}}$ & $3.27^{\mathrm{ab}}$ & $3.27^{\mathrm{ab}}$ & $3.47^{\mathrm{a}}$ & $3.44^{\mathrm{a}}$ & 0.14 & 0.02 & $<0.01$ & 0.91 \\
\hline Fat yield, kg/d & 1.14 & 1.20 & 1.24 & 1.23 & 1.24 & 0.05 & 0.29 & 0.06 & 0.29 \\
\hline True protein, \% & 3.09 & 3.15 & 3.09 & 3.18 & 3.16 & 0.05 & 0.13 & 0.12 & 0.98 \\
\hline True protein yield, kg/d & 1.10 & 1.15 & 1.18 & 1.13 & 1.15 & 0.03 & 0.10 & 0.24 & 0.09 \\
\hline Lactose, \% & 4.91 & 4.89 & 4.94 & 4.91 & 4.92 & 0.04 & 0.71 & 0.58 & 0.95 \\
\hline Lactose yield, kg/d & 1.78 & 1.81 & 1.91 & 1.78 & 1.82 & 0.06 & 0.13 & 0.64 & 0.15 \\
\hline SNF, $\%$ & 8.92 & 8.96 & 8.93 & 9.01 & 9.00 & 0.07 & 0.33 & 0.08 & 0.94 \\
\hline SNF yield, kg/d & 3.21 & 3.30 & 3.44 & 3.24 & 3.31 & 0.09 & 0.11 & 0.47 & 0.11 \\
\hline
\end{tabular}

${ }^{\mathrm{a}, \mathrm{b}}$ Means in the same row without common superscripts differ $(P<0.05)$.

${ }^{1}$ Probability of a significant effect of dietary CP or of a linear (L) or quadratic (Q) effect of dietary CP.

${ }^{2}$ Standard error of the least squares means.

dietary CP concentrations. Therefore, it appears that, under some circumstances, feeding diets with about $16.0 \%$ or less CP (DM basis) provides insufficient MP for maximal milk synthesis, but feeding diets with more than $17.0 \%$ CP does not improve milk yield.

\section{Intake, Digestibility, and Ruminal Metabolism}

Intake of ADF was significantly altered by diet $(P=$ $0.02)$, including a linear increase $(P<0.01)$ with increasing CP content (Table 4), which probably reflected the replacement of RHMSC (2.0\% ADF) with SSBM (4.6\% $\mathrm{ADF})$. Apparent total tract digestibility of $\mathrm{DM}, \mathrm{OM}$, $\mathrm{NDF}$, and $\mathrm{ADF}$ all showed quadratic responses $(P<0.01)$ to increasing dietary CP (Table 4). Digestibilities were lowest at $13.5 \%$, intermediate at 17.9 and $19.4 \%$, and maximal at 15.0 and $16.5 \% \mathrm{CP}$. If RDP supply is lower than the minimum required for microbial growth, intake may be restricted because of depressed ruminal digestion, especially of fiber. Feeding more RDP increases the deamination of AA in the rumen and the supply of branched-chain VFA, which may improve fiber digestion (Misra and Thakur, 2001). The linear increase in acetate concentration in the rumen with increasing dietary $\mathrm{CP}$ (Table 5) also suggested that cellulolytic activity was increased and may be related to the linear increase in milk fat content (Table 3). Ruminal VFA concentrations are related but not equivalent to rates of VFA production and absorption (Sutton et al., 2003) and acetate supply may not directly influence milk fat secretion (Bauman

Table 4. Effect of dietary CP content on intake and estimated apparent digestibility

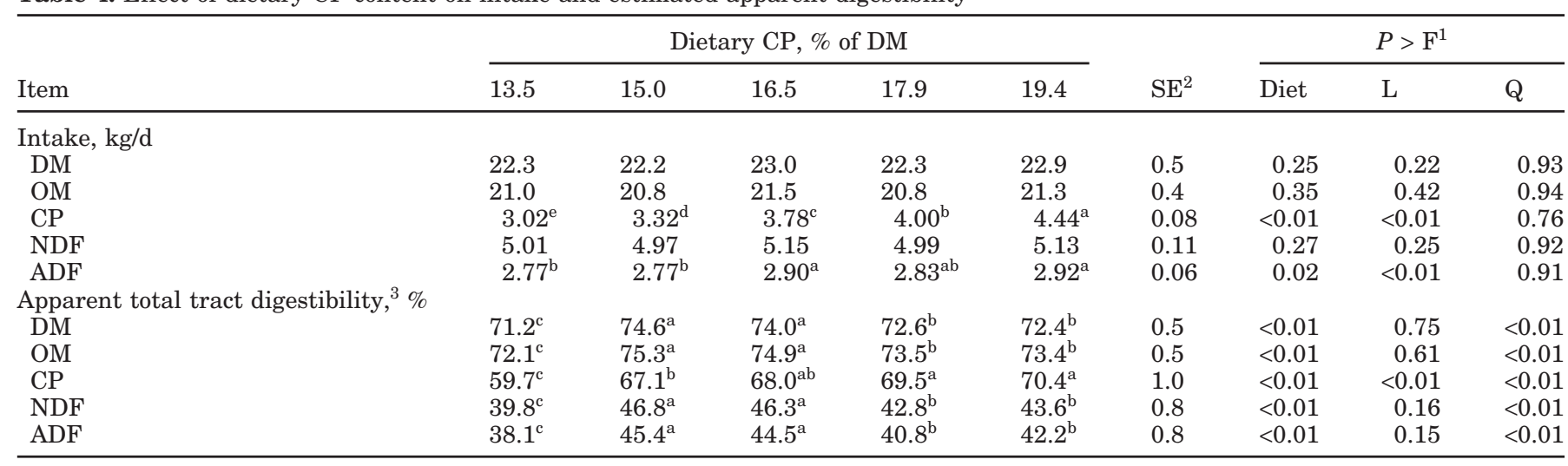

${ }^{\mathrm{a}-\mathrm{e}}$ Means in the same row without common superscripts differ $(P<0.05)$.

${ }^{1}$ Probability of a significant effect of dietary CP or of a linear (L) or quadratic (Q) effect of dietary CP.

${ }^{2}$ Standard error of the least squares means.

${ }^{3}$ Estimated using the indigestible ADF content in TMR and feces as an internal marker. 
Table 5. Effect of dietary CP content on ruminal metabolites

\begin{tabular}{|c|c|c|c|c|c|c|c|c|c|}
\hline \multirow[b]{2}{*}{ Item } & \multicolumn{5}{|c|}{ Dietary CP, \% of DM } & \multirow[b]{2}{*}{$\mathrm{SE}^{2}$} & \multicolumn{3}{|c|}{$P>\mathrm{F}^{1}$} \\
\hline & 13.5 & 15.0 & 16.5 & 17.9 & 19.4 & & Diet & $\mathrm{L}$ & $\mathrm{Q}$ \\
\hline $\mathrm{pH}$ & 6.42 & 6.41 & 6.39 & 6.40 & 6.44 & 0.06 & 0.93 & 0.86 & 0.34 \\
\hline $\mathrm{NH}_{3} \mathrm{~N}, \mathrm{mg} / \mathrm{dL}$ & $6.1^{\mathrm{d}}$ & $7.7^{\mathrm{c}}$ & $9.2^{\mathrm{b}}$ & $12.7^{\mathrm{a}}$ & $12.8^{\mathrm{a}}$ & 0.7 & $<0.01$ & $<0.01$ & 0.56 \\
\hline Free $\mathrm{AA}, \mathrm{m} M$ & 4.69 & 4.63 & 5.13 & 5.36 & 4.66 & 0.50 & 0.71 & 0.64 & 0.40 \\
\hline Acetate (A), $\mathrm{m} M$ & 45.1 & 48.4 & 49.0 & 49.9 & 50.9 & 2.2 & 0.29 & 0.03 & 0.56 \\
\hline Propionate $(\mathrm{P}), \mathrm{m} M$ & 18.5 & 20.1 & 20.9 & 19.0 & 18.5 & 1.4 & 0.28 & 0.74 & 0.05 \\
\hline $\mathrm{A}: \mathrm{P}$ & $2.63^{\mathrm{c}}$ & $2.58^{\mathrm{c}}$ & $2.50^{\mathrm{c}}$ & $2.77^{\mathrm{b}}$ & $2.91^{\mathrm{a}}$ & 0.14 & $<0.01$ & $<0.01$ & $<0.01$ \\
\hline Butyrate, $\mathrm{m} M$ & 9.7 & 9.5 & 9.9 & 10.6 & 10.1 & 0.5 & 0.58 & 0.21 & 0.90 \\
\hline Isobutyrate, $\mathrm{m} M$ & $1.03^{\mathrm{b}}$ & $1.10^{\mathrm{ab}}$ & $1.13^{\mathrm{ab}}$ & $1.17^{\mathrm{a}}$ & $1.20^{\mathrm{a}}$ & 0.05 & 0.02 & $<0.01$ & 0.58 \\
\hline Valerate, $\mathrm{m} M$ & 2.12 & 2.06 & 2.15 & 1.88 & 1.76 & 0.22 & 0.35 & 0.06 & 0.44 \\
\hline Isovalerate, $\mathrm{m} M$ & 1.54 & 1.70 & 1.72 & 1.74 & 1.74 & 0.09 & 0.19 & 0.04 & 0.24 \\
\hline Total VFA, $\mathrm{m} M$ & 78.0 & 83.0 & 84.7 & 84.1 & 84.3 & 4.0 & 0.58 & 0.17 & 0.33 \\
\hline
\end{tabular}

${ }^{\mathrm{a}-\mathrm{d}}$ Means in the same row without common superscripts differ $(P<0.05)$.

${ }^{1}$ Probability of a significant effect of dietary CP or of a linear (L) or quadratic (Q) effect of dietary CP.

${ }^{2}$ Standard error of the least squares means.

and Griinari, 2001). However, there was a linear trend for increased fat yield with increasing dietary CP (Table 3 ) that paralleled the linear increases in ADF digestibility (Table 4) and ruminal acetate concentration (Table 5). Cunningham et al. (1996) found linear increases in $\mathrm{NDF}$ and ADF intake when increasing the CP content of the diet from 14.4 to 16.4 and $18.4 \%$ but no effects on ruminal digestibility of fiber or OM. Christensen et al. (1993) did not detect improvement in intake or apparent ruminal digestibility of $\mathrm{OM}, \mathrm{NDF}$, and $\mathrm{ADF}$ when increasing the CP content of the diet from 16.4 to $19.6 \%$ of DM. Total tract digestibility of CP showed a linear and quadratic response to dietary $\mathrm{CP}$ and its maximum was observed on the $19.4 \% \mathrm{CP}$ diet. This probably reflected the progressively greater dilution of metabolic fecal $\mathrm{N}$ with increasing dietary SSBM, thus increasing apparent $\mathrm{N}$ digestibility on the higher $\mathrm{CP}$ diets (Holter et al., 1982).

Ruminal $\mathrm{pH}$, and concentrations of total free AA, butyrate, and total VFA were not affected by the percentage of $\mathrm{CP}$ in the diet. However, concentrations of $\mathrm{NH}_{3}$, acetate, isobutyrate, and isovalerate all increased linearly, and that of propionate increased quadratically, in response to dietary CP (Table 5). Concentration of valerate showed a trend $(P=0.06)$ for a linear decline. Acetate:propionate ratio also showed a quadratic response to dietary CP level; however, the square $\times$ treatment interaction was significant $(P=0.02)$ for this variable. Linear increases in ruminal concentration of $\mathrm{NH}_{3}$ and branched-chain VFA were not unexpected because SSBM, which was added to increase CP content of diets, is high in RDP (NRC, 2001; Reynal and Broderick, 2003). As dietary CP and RDP increased, there would be greater deamination of AA released from protein degradation, which would elevate concentrations of these metabolites. Sannes et al. (2002) observed higher concentrations of $\mathrm{NH}_{3}$ and branched-chain VFA when the CP content of the diets was increased from 17.2 to $19.1 \%$. Cunningham et al. (1996) and Christensen et al. (1993) also found higher concentrations of $\mathrm{NH}_{3}$ in the rumen in response to higher CP supplementation; however, concentrations of branched-chain VFA were not altered in those studies.

\section{Nitrogen Metabolism and Excretion}

Data on variables related to $\mathrm{N}$ metabolism and use are in Table 6. Concentrations of BUN and MUN, urine volume, and urinary excretion of total $\mathrm{N}$ and urea $\mathrm{N}$ all increased significantly in response to dietary $\mathrm{CP}$ content. Purine derivative (allantoin plus uric acid) excretion showed a linear trend in response to increasing CP content of the diets, whereas excretion of $\mathrm{N}$ in feces as a proportion of $\mathrm{N}$ intake showed linear and quadratic declines.

High concentrations of blood urea, the end product of $\mathrm{N}$ metabolism, are indicative of inefficient use of dietary CP by dairy cows (Broderick and Clayton, 1997). Blood urea rapidly equilibrates with milk (Gustafsson and Palmquist, 1993), resulting in a high correlation between these 2 variables (Broderick and Clayton, 1997). In the present study, blood urea $\mathrm{N}$ increased from 10.7 to 24.0 $\mathrm{mg} / \mathrm{dL}$, and MUN increased from 7.7 to $15.6 \mathrm{mg} / \mathrm{dL}$, when CP content of the diet increased from 13.5 to $19.4 \%$. The correlation between these 2 variables was high $(\mathrm{r}=0.83)$.

Secretion of milk protein N (milk true protein/6.38; Table 6), of course, showed the same quadratic trend $(P=0.09)$ in response to dietary $\mathrm{CP}$ as milk protein yield (Table 3). There was a highly significant linear decline in apparent $\mathrm{N}$ efficiency (milk protein $\mathrm{N} / \mathrm{N}$ intake) as dietary CP increased, decreasing from $36.5 \%$ at $13.5 \%$ $\mathrm{CP}$ to $25.4 \%$ at $19.4 \% \mathrm{CP}$. Increasing CP from 16.5 to $19.4 \%$ depressed $\mathrm{N}$ efficiency by 5.4 percentage units. Broderick (2003) found that $\mathrm{N}$ efficiency decreased from 
Table 6. Effect of dietary CP content on $\mathrm{N}$ metabolism

\begin{tabular}{|c|c|c|c|c|c|c|c|c|c|}
\hline \multirow[b]{2}{*}{ Item } & \multicolumn{5}{|c|}{ Dietary $\mathrm{CP}, \%$ of DM } & \multirow[b]{2}{*}{$\mathrm{SE}^{2}$} & \multicolumn{3}{|c|}{$P>\mathrm{F}^{1}$} \\
\hline & 13.5 & 15.0 & 16.5 & 17.9 & 19.4 & & Diet & $\mathrm{L}$ & $\mathrm{Q}$ \\
\hline $\mathrm{N}$ intake, $\mathrm{g} / \mathrm{d}$ & $483^{\mathrm{e}}$ & $531^{\mathrm{d}}$ & $605^{\mathrm{c}}$ & $641^{\mathrm{b}}$ & $711^{\mathrm{a}}$ & 13 & $<0.01$ & $<0.01$ & 0.75 \\
\hline $\mathrm{MUN}, \mathrm{mg} / \mathrm{dL}$ & $7.7^{\mathrm{d}}$ & $8.5^{\mathrm{d}}$ & $11.2^{\mathrm{c}}$ & $13.0^{\mathrm{b}}$ & $15.6^{\mathrm{a}}$ & 0.5 & $<0.01$ & $<0.01$ & 0.08 \\
\hline Milk protein $\mathrm{N},{ }^{3} \mathrm{~g} / \mathrm{d}$ & 173 & 180 & 185 & 177 & 180 & 5 & 0.11 & 0.25 & 0.09 \\
\hline Milk protein $\mathrm{N}, \%$ of $\mathrm{N}$ intake & $36.5^{\mathrm{a}}$ & $34.0^{\mathrm{b}}$ & $30.8^{\mathrm{c}}$ & $27.5^{\mathrm{d}}$ & $25.4^{\mathrm{e}}$ & 0.8 & $<0.01$ & $<0.01$ & 0.80 \\
\hline \multicolumn{10}{|l|}{ Urinary excretion } \\
\hline Total N, \% of $N$ intake & $23.8^{\mathrm{e}}$ & $26.6^{\mathrm{d}}$ & $29.8^{\mathrm{c}}$ & $33.2^{\mathrm{b}}$ & $36.2^{\mathrm{a}}$ & 0.9 & $<0.01$ & $<0.01$ & 0.79 \\
\hline Urea $\mathrm{N}, \mathrm{g} / \mathrm{d}$ & $63^{\mathrm{e}}$ & $91^{\mathrm{d}}$ & $128^{\mathrm{c}}$ & $174^{\mathrm{b}}$ & $208^{\mathrm{a}}$ & 5 & $<0.01$ & $<0.01$ & 0.19 \\
\hline Urea N, \% of total urinary $\mathrm{N}$ & $55.4^{\mathrm{d}}$ & $64.7^{\mathrm{c}}$ & $72.1^{\mathrm{b}}$ & $81.8^{\mathrm{a}}$ & $81.8^{\mathrm{a}}$ & 1.3 & $<0.01$ & $<0.01$ & $<0.01$ \\
\hline Allantoin, mmol/d & 286 & 303 & 315 & 312 & 315 & 11 & 0.12 & 0.02 & 0.21 \\
\hline Uric acid, mmol/d & $29.0^{\mathrm{a}}$ & $29.8^{\mathrm{a}}$ & $26.3^{\mathrm{ab}}$ & $24.8^{\mathrm{b}}$ & $24.0^{\mathrm{b}}$ & 1.5 & $<0.01$ & $<0.01$ & 0.77 \\
\hline Purine derivatives, $\mathrm{mmol} / \mathrm{d}$ & 314 & 333 & 341 & 336 & 339 & 12 & 0.30 & 0.08 & 0.22 \\
\hline \multicolumn{10}{|l|}{ Fecal excretion } \\
\hline
\end{tabular}

${ }^{\mathrm{a}-\mathrm{e}}$ Means in the same rows without common superscripts differ $(P<0.05)$

${ }^{1}$ Probability of a significant effect of dietary CP or of a linear (L) or quadratic (Q) effect of dietary CP.

${ }^{2}$ Standard error of the least squares means.

${ }^{3}$ Milk protein $\mathrm{N}=$ milk true protein/6.38.

30.3 to 27.0 and $23.4 \%$ when the $\mathrm{CP}$ content of the diet was increased from 15.1 to 16.7 and $18.4 \%$.

Estimated urine volume increased from 17.3 to 21.7 $\mathrm{L} / \mathrm{d}$ in response to higher $\mathrm{CP}$ supplementation. This has also been observed in a number of total collection studies. For instance, Sannes et al. (2002) reported that urinary excretion increased from 22.2 to $25.6 \mathrm{~L} / \mathrm{d}$ when dietary $\mathrm{CP}$ was increased from 17.2 to $19.1 \%$. These data indicated that greater urine volume was required for excreting the excess of $\mathrm{N}$ consumed by the cows (Holter et al., 1982). As the CP content of the diet increased, the proportion of $\mathrm{N}$ intake excreted in the urine also increased, going from $23.8 \%$ of $\mathrm{N}$ intake at $13.5 \% \mathrm{CP}$ to $36.2 \%$ at $19.4 \% \mathrm{CP}$. Moreover, an elevated proportion of the urinary $\mathrm{N}$ was excreted as urea: urea $\mathrm{N}$ increased from $55.4 \%$ of total urinary $\mathrm{N}$ at $13.5 \% \mathrm{CP}$ to $81.8 \%$ at $19.4 \%$ CP. These results clearly showed that any increase on $\mathrm{N}$ intake in diets higher than $16.5 \% \mathrm{CP}$ was lost mainly as urinary urea.

Castillo et al. (2001), from an extensive review of published studies, reported that on average, $72 \%$ of the $\mathrm{N}$ consumed by dairy cows was excreted in feces and urine and that there was a linear relationship between $\mathrm{N}$ intake and $\mathrm{N}$ excreted in feces and urine. Moreover, above $400 \mathrm{~g} / \mathrm{d}$ of $\mathrm{N}$ intake, the proportion of $\mathrm{N}$ excreted in urine increased exponentially whereas proportionate $\mathrm{N}$ output in feces and milk declined linearly. Castillo et al. (2001) suggested that a reduction in dietary CP from 19.0 to $15.0 \%$ of diet $\mathrm{DM}$ would reduce urinary $\mathrm{N}$ excretion from 225 to $151 \mathrm{~g} / \mathrm{d}$ without significantly altering milk production.
Urinary excretion of purine derivatives, of which allantoin is the major component, reflects microbial nucleic acid absorption from the small intestine and is related to microbial protein formation in the rumen (Stangassinger et al., 1995). There was a linear increase $(P=$ $0.02)$ in urinary allantoin excretion, and a trend $(P=$ 0.09 ) for a linear increase in excretion of total purine derivatives, with increasing dietary CP (Table 6). However, excretion of allantoin and total purine derivatives did not increase numerically above $16.5 \%$ dietary $\mathrm{CP}$, suggesting no elevation in bacterial $\mathrm{CP}$ formation in the rumen beyond this point. Ruminal $\mathrm{NH}_{3} \mathrm{~N}$ concentrations less than $5 \mathrm{mg} / \mathrm{dL}$ may limit microbial protein formation (Satter and Slyter, 1974). Over the course of the day, ruminal $\mathrm{NH}_{3} \mathrm{~N}$ was less than $5 \mathrm{mg} / \mathrm{dL}$ for several hours on both 13.5 and $15.0 \%$ CP diets but was never lower than this concentration on the other 3 diets (Figure 1). Direct determinations of microbial protein flow from the rumen in this trial, measured using ${ }^{15} \mathrm{~N}$ as microbial marker and omasal sampling, are reported in the companion paper (Olmos Colmenero and Broderick, 2006).

\section{Optimal Dietary CP}

Regression coefficients as well as estimated optima of dietary CP concentration for the 13 variables showing quadratic responses $(P \leq 0.10)$ to dietary $\mathrm{CP}$ level are in Table 7. Dietary CP optima ranged from 14.7 to $20.9 \%$ with an overall mean of $17.0 \%$. However, optima for milk and protein yield, the most economically important responses, were 16.7 and $17.1 \% \mathrm{CP}$, respectively. Quad- 


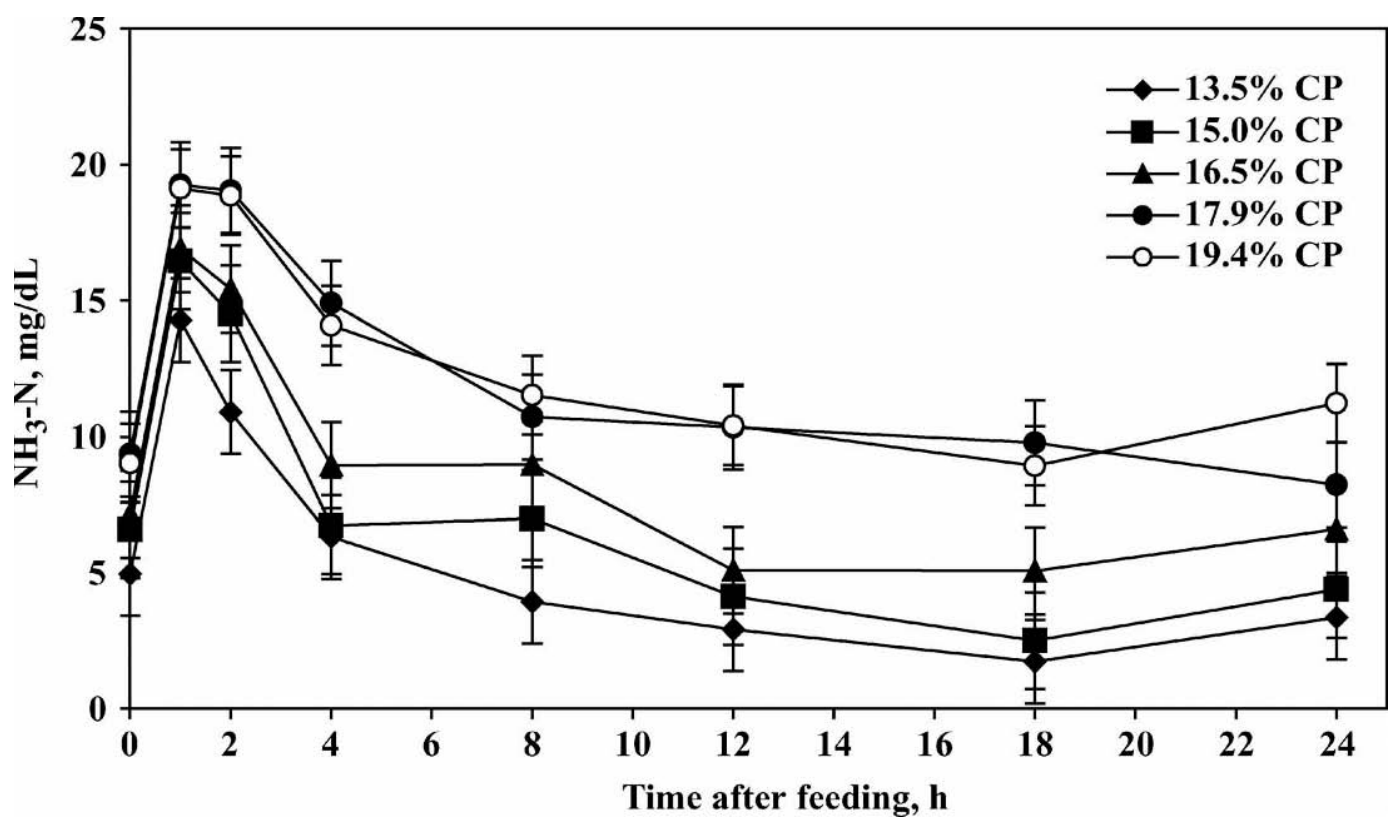

Figure 1. Effect of dietary CP content on ruminal ammonia concentrations after feeding (error bars are \pm 1 SEM).

ratic responses in yield of milk and protein to increasing dietary CP were obtained using large databases by NRC (2001), Huhtanen and Shingfield (2005), and Ipharraguerre and Clark (2005). However, all 3 sources reported regressions indicating that milk and protein production was maximal when the diet contained from 21 to $23 \%$ CP. The optima for apparent total tract digestibility of $\mathrm{DM}, \mathrm{OM}, \mathrm{NDF}$, and ADF averaged $16.6 \% \mathrm{CP}$. The optima (minima) for the variables related to $\mathrm{N}$ excretion in feces were, on average, $16.8 \% \mathrm{CP}$.

\section{CONCLUSIONS}

When feeding diets based on alfalfa and corn silages, with RHMSC as the main source of NFC and SSBM as the main supplemental protein, $16.5 \% \mathrm{CP}$ was sufficient for maximizing production of milk and protein. A linear increase in urinary $\mathrm{N}$ excretion resulted in a substantial decline in $\mathrm{N}$ efficiency as dietary $\mathrm{CP}$ content was increased from 13.5 to $19.4 \%$. Results from this study indicated that diets containing $16.5 \% \mathrm{CP}$ supported maximal production in dairy cows with minimal $\mathrm{N}$ excretion to the environment compared with diets with higher CP content.

\section{ACKNOWLEDGMENTS}

The authors wish to thank the farm crew for harvesting and storing the feedstuffs used in this trial; Len Strozinski and the barn crew for feeding and animal

Table 7. Regression coefficients and optimal dietary CP concentrations for traits with significant quadratic effects $(P \leq 0.10)$

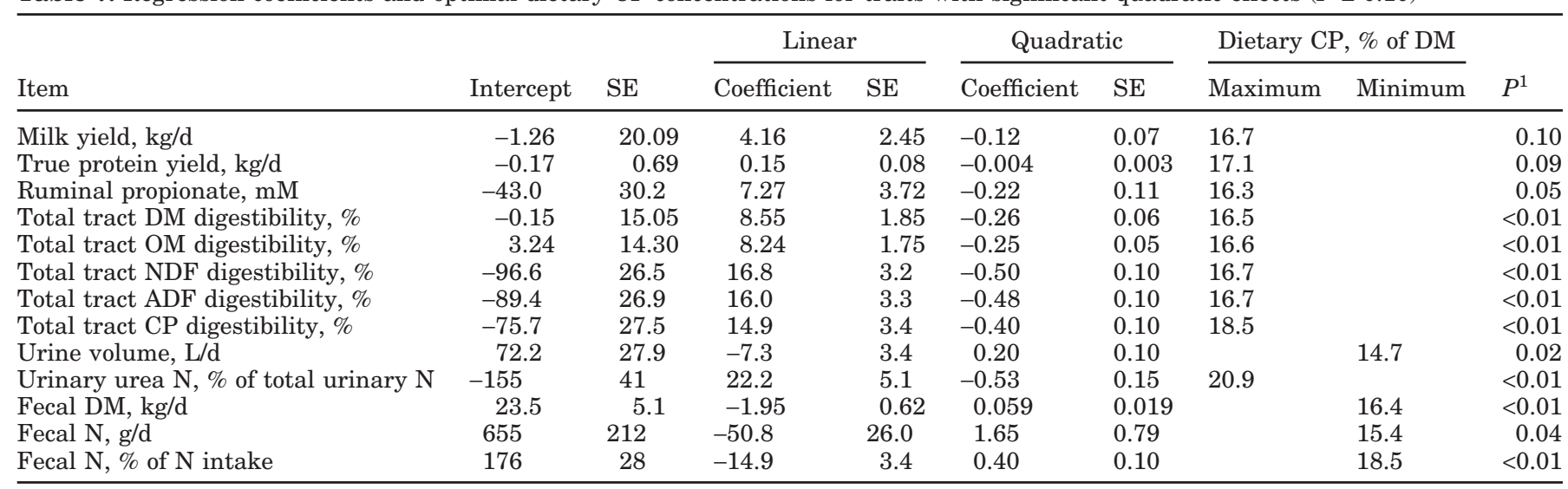

${ }^{1}$ Probability of quadratic effect of dietary CP content. 
care at the US Dairy Forage Center Research Farm (Prairie du Sac, WI); Wendy Radloff and Mary Becker for conducting laboratory analyses; and Peter Crump for aiding with statistical analyses. The first author also thanks Consejo Nacional de Ciencia y Tecnologia (CONACyT) Mexico, and Universidad de Guadalajara (Jalisco, Mexico) for partial financial support.

\section{REFERENCES}

AOAC. 1980. Official Methods of Analysis. 13th ed. Association of Official Analytical Chemists, Washington, DC.

Bauman, D. E., and J. M. Griinari. 2001. Regulation and nutritional manipulation of milk fat: Low-fat milk syndrome. Livest. Prod. Sci. 70:15-29.

Broderick, G. A. 1995. Desirable characteristics of forage legumes for improving protein utilization in ruminants. J. Anim. Sci. 73:2760-2773.

Broderick, G. A. 2003. Effects of varying dietary protein and energy levels on the production of lactating dairy cows. J. Dairy Sci. 86:1370-1381.

Broderick, G. A., and M. K. Clayton. 1997. A statistical evaluation of animal and nutritional factors influencing concentrations of milk urea nitrogen. J. Dairy Sci. 80:2964-2971.

Broderick, G. A., P. Udén, M. L. Murphy, and A. Lapins. 2004. Sources of variation in rates of in vitro rumen protein degradation. J. Dairy Sci. 87:1345-1359.

Brotz, P. G., and D. M. Schaefer. 1987. Simultaneous determination of lactic acid and volatile fatty acids in microbial fermentation extracts by gas-liquid chromatography. J. Microbiol. Methods 6:139-144.

Castillo, A. R., E. Kebreab, D. E. Beever, and J. France. 2001. A review of efficiency of nitrogen utilisation in lactating dairy cows and its relationship with environmental pollution. J. Anim. Feed Sci. $9: 1-32$.

Christensen, R. A., M. R. Cameron, T. H. Klusmeyer, J. P. Elliot, J. H. Clark, D. R. Nelson, and Y. Yu. 1993. Influence of amount and degradability of dietary protein on nitrogen utilization by dairy cows. J. Dairy Sci. 76:3497-3513.

Cunningham, K. D., M. J. Cecava, T. R. Johnson, and P. A. Ludden. 1996. Influence of source and amount of dietary protein on milk yield by cows in early lactation. J. Dairy Sci. 79:620-630.

Gustafsson, A. H., and D. L. Palmquist. 1993. Diurnal variation of rumen ammonia, serum urea, and milk urea in dairy cows at high and low yields. J. Dairy Sci. 76:475-484.

Gunderson, S., J. Keuning, and R. Shaver. 1998. 30,000 pounds and beyond... a survey of six of Wisconsin's top producing dairy herds. http://www.wisc.edu/dysci/uwex/nutritn/pubs/30000.html Accessed Mar. 30, 2005.

Hintz, R. W., D. R. Mertens, and K. A. Albrecht. 1995. Effects of sodium sulfite on recovery and composition of detergent fiber and lignin. J. AOAC 78:16-22.

Holter, J. B., J. A. Byrne, and C. G. Schwab. 1982. Crude protein for high milk production. J. Dairy Sci. 65:1175-1188.

Huhtanen, P., K. Kaustell, and S. Jaakkola. 1994. The use of internal markers to predict total digestibility and duodenal flow of nutrients in cattle given 6 different diets. Anim. Feed Sci. Technol. 48:211-227.

Huhtanen, P., and K. J. Shingfield. 2005. Grass silage: Factors affecting efficiency of $\mathrm{N}$ utilization in milk production. Pages 35-50 in Silage Production and Utilisation, Proc. XIVth Int. Silage Conf., Belfast,
UK. R. S. Park and M. D. Stronge, ed. Wageningen Academic Publ., Wageningen, The Netherlands.

Ipharraguerre, I. R., and J. H. Clark. 2005. Impacts of the source and amount of crude protein on the intestinal supply of nitrogen fractions and performance of dairy cows. J. Dairy Sci. 88(E Suppl.):E22-E37.

Leonardi, C., M. Stevenson, and L. E. Armentano. 2003. Effect of two levels of crude protein and methionine supplementation on performance of dairy cows. J. Dairy Sci. 86:4033-4042.

Misra, A. K., and S. S. Thakur. 2001. Effect of dietary supplementation of sodium salt of isobutyric acid on ruminal fermentation and nutrient utilization in a wheat straw based low protein diet fed to crossbred cattle. Asian-Austral. J. Anim. Sci. 14:479-484.

Muck, R. E. 1982. Urease activity in bovine feces. J. Dairy Sci. 65:2157-2163.

Muck, R. E. 1987. Dry matter level effects on alfalfa silage quality. 1. Nitrogen transformations. Trans. Am. Soc. Agric. Eng. 30:7-14.

Nagel, S. A., and G. A. Broderick. 1992. Effect of formic acid or formaldehyde treatment of alfalfa silage on nutrient utilization by dairy cows. J. Dairy Sci. 75:140-154.

National Research Council. 2001. Nutrient Requirements of Dairy Cows. 7th rev. ed. Natl. Acad. Sci., Washington, DC.

Olmos Colmenero, J. J., and G. A. Broderick. 2006. Effect of dietary crude protein concentration on ruminal nitrogen metabolism in lactating dairy cows. J. Dairy Sci. 89:1694-1703.

Oser, B. L. 1965. Hawk's Physiological Chemistry. 14 ed. McGrawHill, New York, NY.

Reynal, S. M., and G. A. Broderick. 2003. Effects of feeding dairy cows protein supplements of varying ruminal degradability. J. Dairy Sci. 86:835-843.

Reynal, S. M., and G. A. Broderick. 2005. Effect of dietary level of rumen-degraded protein on production and nitrogen metabolism in lactating dairy cows. J. Dairy Sci. 88:4045-4064.

Sannes, R. A., M. A. Messman, and D. B. Vagnoni. 2002. Form of rumen-degradable carbohydrate and nitrogen on microbial protein synthesis and protein efficiency of dairy cows. J. Dairy Sci. 85:900-908.

Santos, F. A. P., J. E. P. Santos, C. B. Theurer, and J. T. Huber. 1998. Effects of rumen-undegradable protein on dairy cow performance: A 12-year literature review. J. Dairy Sci. 81:3182-3213.

SAS Institute. 1999-2000. SAS/STAT User's Guide. Release 8.1. SAS Institute, Inc., Cary, NC.

Satter, L. D., and L. L. Slyter. 1974. Effect of ammonia concentration on rumen microbial protein production in vitro. Br. J. Nutr. 32:199-208.

Stangassinger, M., X. B. Chen, J. E. Lindberg, and D. Giesecke. 1995. Metabolism of purines in relation to microbial production. Pages 387-406 in Ruminant Physiology: Digestion, Metabolism, Growth and Reproduction. W. V. Engelhardt, S. Leonhard-Marek, G. Breves, and D. Giesecke, ed. Ferdinand Enke Verlag, Stuttgart, Germany.

Sutton, J. D., M. S. Dhanoa, S. V. Morant, J. France, D. J. Napper, and E. Schuller. 2003. Rates of production of acetate, propionate, and butyrate in the rumen of lactating dairy cows given normal and low-roughage diets. J. Dairy Sci. 86:3620-3633.

Valadares, R. F. D., G. A. Broderick, S. C. Valadares Filho, and M. K. Clayton. 1999. Effect of replacing alfalfa silage with high moisture corn on ruminal protein synthesis estimated from excretion of total purine derivatives. J. Dairy Sci. 82:2686-2696.

Van Soest, P. J., J. B. Robertson, and B. A. Lewis. 1991. Methods for dietary fiber, neutral detergent fiber and nonstarch polysaccharides in relation to animal nutrition. J. Dairy Sci. 74:3583-3597.

Vogels, G. D., and C. van der Drift. 1970. Differential analyses of glyoxylate derivatives. Anal. Biochem. 33:143-157. 